Bangladesh J. Zool. 42(2): 227-236, 2014

\title{
MICROBIAL AND PROXIMATE COMPOSITION OF FRESH AND SALTED HILSA, TENUALOSA ILISHA
}

\author{
Tahara Rohomania, Mihir Lal Saha¹, Anwar Hossain, Shankar Chandra Mandal \\ and Mohammad Shamsur Rahman* \\ Department of Fisheries, Faculty of Biological Sciences, University of Dhaka, \\ Dhaka-1000, Bangladesh
}

\begin{abstract}
Bacterial and nutritional quality of fresh and salted hilsa collected from four markets of Dhaka city were investigated. Five different culture media viz. nutrient agar, EMB agar for coliform, SS agar for Salmonella-Shigella, MSA agar for Staphylococcus and TCBS for Vibrio were used. The highest heterotrophic bacterial count $1.22 \pm 0.12 \times 10^{6} \mathrm{cfu} / \mathrm{g}$ was recorded in the fresh fish sample of Karwan Bazar. Maximum coliform count, $1.20 \pm 0.10 \times 10^{6} \mathrm{cfu} / \mathrm{g}$ was detected in the fresh fish sample of the same market. No bacterial colony was found on SS agar and TCBS agar plate in salted fish. Proximate composition of raw hilsa of dorsal and ventral part was $56.49 \pm 0.13 \%$ and $55.45 \pm 0.06 \%$ moisture, $23.62 \pm$ $0.28 \%$ and $22.99 \pm 0.36 \%$ protein, $18.01 \pm 0.39 \%$ and $18.96 \pm 0.43 \%$ fat and 1.71 $\pm 0.04 \%$ and $2.26 \pm 0.09 \%$ ash, respectively. In salted $T$. ilisha, the proximate composition of dorsal and ventral part was $45.13 \pm 0.54 \%$ and $40.20 \pm 0.20 \%$ moisture, $20.79 \pm 0.17 \%$ and $21.48 \pm 0.15 \%$ protein, $16.89 \pm 0.47 \%$ and $19.54 \pm$ $0.26 \%$ lipid and $16.65 \pm 0.41 \%$ and $18.35 \pm 0.08 \%$ ash. The fresh fish samples were associated with high bacterial loads than that of salted fish. The protein, lipid, moisture contents decreased and ash content increased after salting condition.
\end{abstract}

Key words: Salted Hilsa, Fresh Hilsa, Bacterial and Nutritional quality.

\section{INTRODUCTION}

Hilsa (Tenualosa ilisha) is a popular, highly nutritious, diadromous fish found in the rivers of Bangladesh round the year and are available in local markets both fresh and salted condition. It is considered as the national fish due to its popularity and economic importance (DOF 2013).

Fish are highly perishable food item for which they start to spoil as soon as they are harvested (Balachandran 2001). So processing and storage method is a vital factor in fish consumption. On the way of transportation from each point to market, there is a great chance for the fish to be contaminated by bacteria (Clucas and Ward 1996). The qualities of frozen fish is determined mainly by the

*Author for correspondence: <shamsur@du.ac.bd>. ${ }^{1}$ Department of Botany, Faculty of Biological Sciences, University of Dhaka, Dhaka-1000, Bangladesh. 
total number of bacteria present and by the individual count of bacteria of public health significance such as Escherichia coli, Staphylococcus, Vibrio cholerae, Salmonella etc.

Preservation of fish by salt is an old age technology. This method of preservation still enjoys popularity in many developing countries owing to its simplicity and low cost of processing (Takagi et al. 1984). Salted hilsa (Locally known as 'Lona ilish') is a salt fermented product prepared from the Indian shad (Tenualosa ilisha). It is a very popular and widely consumed in Bangladesh mainly due to its typical flavor, aroma and texture. Though the spoilage of salted fish is less severe but it is usually contaminated with the harmful bacteria and the fungi; because in glut period, only those fish are spoiled or partially spoiled and cannot be sold in the fresh wet fish market are used for salting (Alam 2010).

Biochemical composition of fish flesh may vary within the same species of fish depending upon the fishing season, age, sex and habitat (Srivastava 1985). The variation is also found within the different region of the body (Jacquot 1961). Fish flesh contains four basic components in varying proportions such as water $(70-80 \%)$, protein $(18-20 \%)$, fat $(5 \%)$ and minerals $(5 \%)$ (Khurseed and Mosharaff 1998). It has high nutritional value in terms of fats and proteins. Consumption of different types of food by the fish species make proximate composition a bit different and also different part of the body makes the composition different as well. The objective of the study was to investigate the bacterial and nutritional status of fresh and salted hilsa (Tenualosa ilisha) collected from local fish markets by determining bacterial load and proximate composition.

\section{MATERIAL AND METHODS}

Hilsa samples (fresh and salted) were collected aseptically from four different fish markets of Dhaka city viz., Palashi Bazaar, Karwan Bazaar, Anando Bazaar and New Market. Fish samples were collected in sterile plastic bags and were labeled. Identification of sampled fish was done according to Rahman (2005) and were preserved in a refrigerator at $4^{\circ} \mathrm{C}$.

Nutrient agar (NA) (Eklund and Lankford 1967) medium was used for the enumeration and isolation of aerobic heterotrophic bacteria present in fish samples, while EMB agar (Scharlau Chemie S.A, Barcelona, Spain), SS agar (Techno Pharmachem, Bahadurgarh, Haryana), Manitol salt agar (MSA) and TCBS agar (Scharlau Chemie S.A, Barcelona, Spain) were used to enumerate and isolate coliform bacteria, Salmonella-Shigella, Staphylococcus and enteropathogenic vibrios respectively.

Serial dilution technique (Clescerl et al. 1999) was used for the isolation of microorganisms. $10 \mathrm{~g}$ of fish muscle was diluted with $90 \mathrm{ml}$ sterile distilled water 
in a sterile conical flask and shaken well. This suspension was transferred to 9 $\mathrm{ml}$ of sterile water for ten-fold $(1: 10)$ dilution and further diluted up to $10^{-4}$ for the plating of NA medium and $10^{-3}$ dilutions for the plating of EMB agar medium and SS agar medium, Manitol salt agar medium, TCBS agar medium.

One $\mathrm{ml}$ of each of the diluted sample was taken in a sterilized petri plate by sterilized pipette. Then molten agar medium poured and mixed thoroughly by rotating the petri plate, first in one direction and then in the opposite direction. Duplicated plating was made for each diluted sample. After setting the medium, the plates were placed inverted and incubated at $37^{\circ} \mathrm{C}$ for $24 \mathrm{~h}$ in an incubator.

After $24 \mathrm{~h}$ of incubation, the plates having well discrete colonies were selected for counting from the respective culture plate. In case of EMB agar medium, pink or metallic green sheen colonies considered as coliform bacteria while white colonies considered as non lactose fermenter. The selected plates placed on colony counter (Digital colony counter, DC-8 OSK 100086, Kayagaki, Japan) and the colonies were counted.

Fresh and salted hilsa were analyzed for their nutrient content in order to have a clear idea about the category of fish where it belongs to. Moisture content was expressed as the amount of water as percentage (\%). Moisture content was determined by oven drying method (AOAC 1995). Crude protein content of fish was determined by micro-Kjeldahl method using Kjeltec machine (Model Tecator Kjeltec System 1026 Manual 1987). Lipid content was determined by extraction with a mixture of chloroform $(2: 1)$ to a little amount of sodium chloride $(0.9 \%)$ as recommended by AOAC (1995). Ash content was determined by ignition of samples in a muffle furnace at $550-600^{\circ} \mathrm{C}$ for 16 hours (AOAC 1995).

Statistical analysis was performed with the Statistical Package for the Social Sciences (SPSS) v. 16.0 for windows (SPSS, SAS Institute Inc. Cary, USA). One way ANOVA was done with 0.05 level of significance.

\section{RESULTS AND DISCUSSION}

Quality is the degree of excellence or grade of goodness. In simple terms, the quality of a food can be defined as those characteristics which make it acceptable to the consumers. Bacteriological quality is of public health importance as it directly relates to spoilage of fish and becomes the cause of outbreak of food poisoning (Nilla et al. 2012).

Bacterial load of the collected samples: The highest heterotrophic bacterial load of fresh fish samples on nutrient agar was $1.22 \pm 0.12 \times 10^{6} \mathrm{cfu} / \mathrm{g}$ found in fresh hilsa from Karwan Bazar while the lowest was $1.40 \pm 0.6 \times 10^{4} \mathrm{cfu} / \mathrm{g}$ found in salted hilsa from Palashi Bazar (Table 1, $(\mathrm{p}<0.05))$. However, significantly 
higher bacterial count was detected in fresh hilsa sampled from Palashi Bazar, Karwan Bazar and Anando Bazar than that of others $(\mathrm{p}<0.05)$ while similar bacterial density was observed in all the samples of salted hilsa and fresh hilsa from New market.

Table 1. Total bacterial count (cfu/g; mean \pm SEM) in Tenualosa ilisha fish sample

\begin{tabular}{lcc}
\hline Source & \multicolumn{2}{c}{ Type of fish } \\
\cline { 2 - 3 } & Fresh & Salted \\
\hline Palashi Bazar & $9.80 \pm 1.20 \times 10^{5 \mathrm{a}}$ & $1.40 \pm 0.6 \times 10^{4 \mathrm{~b}}$ \\
Karwan Bazar & $1.22 \pm 0.12 \times 10^{6 \mathrm{a}}$ & $7.45 \pm 0.55 \times 10^{4 \mathrm{~b}}$ \\
Anando Bazar & $9.30 \pm 1.70 \times 10^{5 \mathrm{a}}$ & $6.85 \pm 3.15 \times 10^{4 \mathrm{~b}}$ \\
New Market & $6.60 \pm 0.20 \times 10^{4 \mathrm{~b}}$ & $7.00 \pm 1.00 \times 10^{4 \mathrm{~b}}$
\end{tabular}

Means followed by different superscript small letters indicate significant differences (ANOVA, HSD; $\mathrm{P}<0.05)$.

Significantly higher enteric bacteria with special reference to coliform count on EMB agar was found in fresh hilsa sampled from Kawran bazaar than that of others $(p<0.05)$. However, significantly higher but similar coliform count was detected in fresh samples from Palashi Bazar, Anando Bazar and New Market than that of salted samples (Table 2).

Significantly higher MSA count was found in fresh hilsa sampled from Karwan Bazar and Anando Bazar than that of others $(\mathrm{P}<0.05)$. However, similar Staphylococcal count was found in raw and salted hilsa sampled from all the markets other than Karwan Bazar and Anando Bazar (Table 3).

Highest Shalmonella-Shigella count $6.35 \pm 1.35 \times 10^{4} \mathrm{cfu} / \mathrm{g}$ was observed in fresh hilsha sampled from Karwan bazaar which was similar to that of Palashi Bazar. No Shalmonella-Shigella count was found in any sample of salted hilsa (Table 4).

Table 2. Total EMB count (cfu/g; mean \pm SEM) in Tenualosa ilisha fish sample

\begin{tabular}{lcc}
\hline Source & \multicolumn{2}{c}{ Type of fish } \\
\cline { 2 - 3 } & Fresh & Salted \\
\hline Palashi Bazar & $2.15 \pm 0.15 \times 10^{5 \mathrm{bc}}$ & $5.20 \pm 0.30 \times 10^{3 \mathrm{c}}$ \\
Karwan Bazar & $1.20 \pm 0.10 \times 10^{6 \mathrm{a}}$ & $8.50 \pm 1.50 \times 10^{3 \mathrm{c}}$ \\
Anando Bazar & $2.66 \pm 0.49 \times 10^{5 \mathrm{~b}}$ & $6.40 \pm 0.40 \times 10^{3 \mathrm{c}}$ \\
New Market & $1.90 \pm 0.40 \times 10^{5 \mathrm{bc}}$ & $7.75 \pm 1.70 \times 10^{4 \mathrm{bc}}$ \\
\hline
\end{tabular}

Means followed by different superscript small letters indicate significant differences (ANOVA, HSD; $\mathrm{P}<0.05)$.

Vibrio like colonies were found only in two samples of fresh hilsa collected from Kawran Bazar and Ananda Bazar (Table 5) which were insignificant to others $(\mathrm{p}<0.05)$. 
Table 3. Total MSA count (cfu/g; mean \pm SEM) in Tenualosa ilisha fish sample

Source

\begin{tabular}{|c|c|c|}
\hline & \\
\hline & Fresh & Salted \\
\hline Palashi Bazar & $5.10 \pm 1.10 \times 10^{4 b}$ & $2.10 \pm 0.20 \times 10^{3 b}$ \\
\hline Karwan Bazar & $1.26 \pm 0.06 \times 10^{5 a}$ & $4.00 \pm 1.00 \times 10^{4 b}$ \\
\hline Anando Bazar & $1.64 \pm 0.24 \times 10^{5 a}$ & $3.20 \pm 0.80 \times 10^{3 b}$ \\
\hline New Market & $2.50 \pm 0.50 \times 10^{2 b}$ & $1.50 \pm 0.50 \times 10^{2 b}$ \\
\hline
\end{tabular}

Means followed by different superscript small letters indicate significant differences (ANOVA, HSD; $\mathrm{P}<0.05)$.

Table 4. Total Salmonella-Shigella count (mean \pm SEM) in Tenualosa ilisha fish sample

\begin{tabular}{lcc}
\hline Source & \multicolumn{2}{c}{ Type of fish } \\
\cline { 2 - 3 } & Fresh & Salted \\
\hline Palashi Bazar & $4.90 \pm 1.10 \times 10^{3 \mathrm{a}}$ & $0.00 \pm 0.00^{\mathrm{b}}$ \\
Karwan Bazar & $6.35 \pm 1.35 \times 10^{4 \mathrm{a}}$ & $0.00 \pm 0.00^{\mathrm{b}}$ \\
Anando Bazar & $1.50 \pm 0.50 \times 10^{2 \mathrm{~b}}$ & $0.00 \pm 0.00^{\mathrm{b}}$ \\
New Market & $0.00 \pm 0.00^{\mathrm{b}}$ & $0.00 \pm 0.00^{\mathrm{b}}$ \\
\hline
\end{tabular}

Means followed by different superscript small letters indicate significant differences (ANOVA, HSD; $\mathrm{P}<0.05)$.

The total bacterial load in raw fish was beyond the acceptable limit $\left(5 \times 10^{5}\right.$ $\mathrm{cfu} / \mathrm{g}$ ) according to the ICMFS except for raw hilsa of New market (ICMFS 1986) which might be due to secondary contamination during the time of handling as well as storage of fishes in ice made from contaminated water. High microbial abundance might be due to contaminated source of water, poor hygiene and sanitation condition of processing (Hatha et al. 1998). The processed food is considered as spoiled when the total bacterial count (TBC) values reach to $10^{6}$ $\mathrm{cfu} / \mathrm{g}$ or more in food items (Shewan 1970). On the other hand, the bacterial density observed in salted hilsa was acceptable respective to total heterotropic bacterial population according to ICMFS (1986).

Table 5. Total TCBS count (mean \pm SEM) in Tenualosa ilisha fish sample

\begin{tabular}{lcc}
\hline Source & \multicolumn{2}{c}{ Type of fish } \\
\cline { 2 - 3 } & $5.00 \pm 5.0 \times 10$ & Salted \\
\hline Palashi Bazar & $5.00 \pm 5.0 \times 10$ & $0.00 \pm 0.00$ \\
Karwan Bazar & $0.00 \pm 0.00$ & $0.00 \pm 0.00$ \\
Anando Bazar & $0.00 \pm 0.00$ & $0.00 \pm 0.00$ \\
New Market & $0.00 \pm 0.00$ \\
\hline
\end{tabular}

Means $( \pm \mathrm{SEM})$ with no letters denote no significant differences (ANOVA, HSD, $\mathrm{p}<0.05$ ).

The highest EMB count was $1.2 \pm 0.1 \times 10^{6} \mathrm{cfu} / \mathrm{g}$ in fresh hilsa collected from Karwan Bazar and lowest was $5.2 \pm 0.3 \times 10^{3} \mathrm{cfu} / \mathrm{g}$ in salted sample collected from New market (Table 2). All samples were observed having high quantity of 
EMB count exceeding the limit $\left(>10^{2} \mathrm{cfu} / \mathrm{g}\right)$ suggested by ICMSF 1986 and proves local markets supply low quality fish. Sultana et al. 2008 found total viable count and total coliform count range from $2.2 \times 10^{5}$ to $5.83 \times 10^{7} \mathrm{cfu} / \mathrm{g}$ and $1.4 \times 10^{2}$ to $7.4 \times 10^{3}$ respectively in salted hilsa which support the findings of the present study.

In one study Munce (1980) stated that presence of coliform in food has been linked with the practice of inadequate hygienic measure, mishandling, improper storage and use of dirty water during marketing and all unhygienic condition of the shops. Moreover, Boyd (1990) suggests that the contamination may also come from the water use for washing or icing. The microbial contamination of the fish samples depend upon the source of the fish, $\mathrm{pH}$, temperature, acidity of the water, natural handling, processing time elapsed between catching and marketing, water used during marketing etc. Depending on the habitat and other environment factors a wide range of variation in distribution of microflora in fish has been reported (Lakshmanan 1999, Ito et al. 1993). No Salmonella and Vibrio was detected in salted hilsa in the present study which is supported by Shamsuzzaman et al. (2011).

Proximate Composition of fresh and salted hilsa: The major constituents in fish are moisture, protein, lipids and ash. Large fluctuations occur in the proximate composition and are influenced by several factors such as species of fish, diet, fishing grounds, season, sex and sexual maturity and spawning.

Moisture is the major component of fish muscle. Significantly higher moisture content was found in both dorsal and ventral portion of fresh hilsa than that of salted ( $p<0.05$, Fig. 1). Moreover, significantly higher moisture was detected in dorsal portion $(45.13 \pm 0.54 \%)$ of salted hilsa than that of ventral $(40.20 \pm 0.20 \%)$. However, similar moisture level was observed in dorsal (56.49 $\pm 0.13 \%)$ and ventral portion $(55.45 \pm 0.06 \%)$ of raw hilsa.

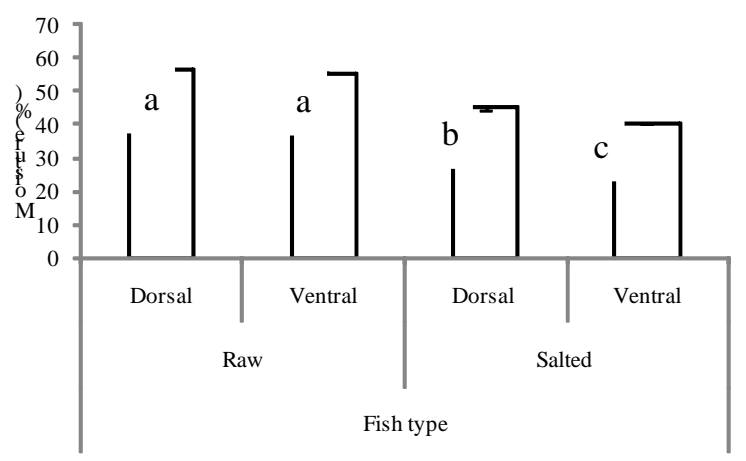

Fig. 1. Moisture contents (\%) of different body portions hilsa. Bars (mean \pm SEM) with different letters are significantly different (ANOVA, HSD; $\mathrm{p}<0.05$ ) 
Significantly higher but similar protein level was detected in dorsal and ventral portion of fresh hilsa than that of salted $(\mathrm{p}<0.05$, Fig. 2). However, similar protein content was observed in dorsal and ventral portion of respective raw and salted hilsa.

Significantly higher lipid content was found in ventral portion of salted hilsa $(19.54 \pm 0.26 \%)$ than that of others $(\mathrm{p}<0.05$, Fig. 3$)$. Moreover, higher lipid level was detected in ventral portion $(18.96 \pm 0.43 \%)$ of fresh hilsa than that of dorsal (18.96 \pm 0.43$)$.

Significantly higher ash content was found in ventral portion of salted hilsa $(18.35 \pm 0.08 \%)$ than that of others ( $<<0.05$, Fig. 4). Moreover, significantly higher ash content was detected in dorsal portion $(16.65 \pm 0.41 \%)$ of salted hilsa than that of dorsal and ventral portion of raw sample. However, similar ash content was detected in dorsal $(1.71 \pm 0.04 \%)$ and ventral $(2.26 \pm 0.09 \%)$ portion of raw hilsa.

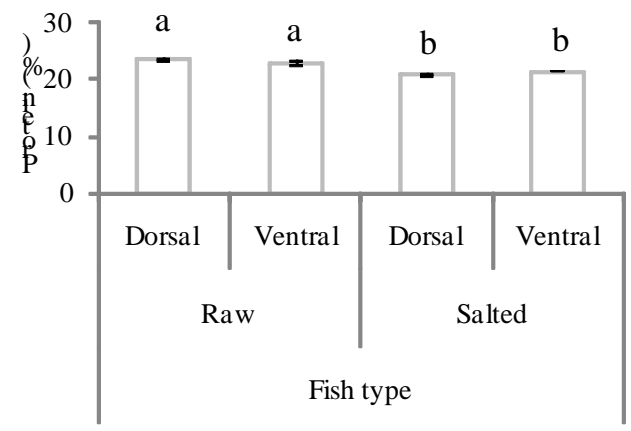

Fig. 2. Protein contents (\%) of different body portions hilsa. Bars (mean \pm SEM) with different letters are significantly different (ANOVA, HSD; $\mathrm{p}<0.05$ )

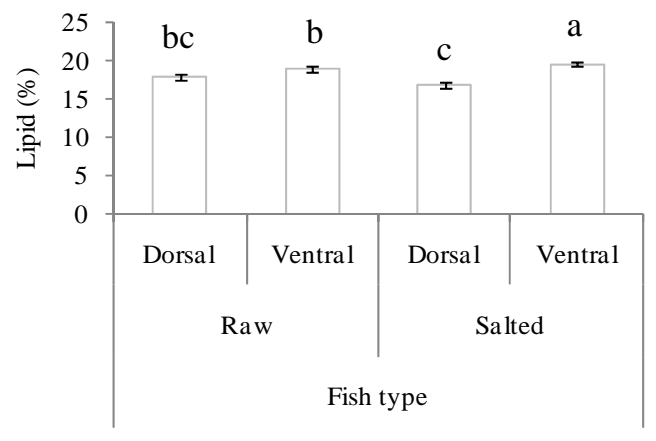

Fig. 3. Lipid contents (\%) of different body portions hilsa. Bars (mean \pm SEM) with different letters are significantly different (ANOVA, HSD; $\mathrm{p}<0.05$ ) 


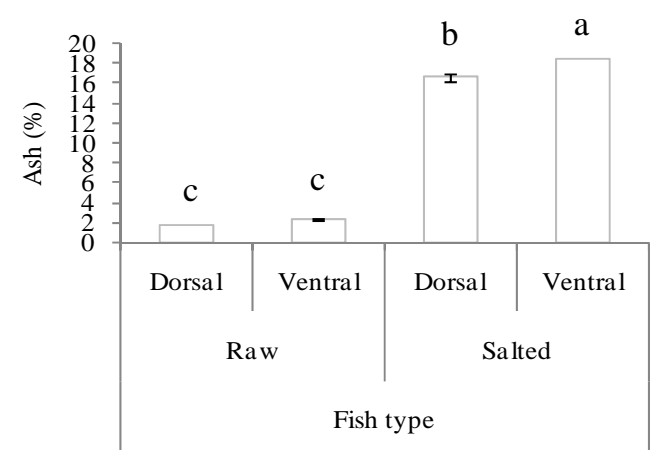

Fig. 4. Ash contents (\%) of different body portions hilsa. Bars (mean \pm SEM) with different letters are significantly different (ANOVA, HSD; $\mathrm{p}<0.05$ )

Immaculate et al. 2013 studied the seasonal variation of moisture content of different salted and sun dried fishes and found high moisture ranged between 48.2 to $58.6 \%$ in monsoon that is similar to our study $(45.13 \pm 0.54 \%)$.

In the present study fat content in fresh hilsa was between $18.01 \pm 0.39$ and $18.96 \pm 0.43 \%$ which is in agreed with Majumder et al. (2005), who stated that fat content in fresh hilsa varies from 14-25\%. Majumdar and Basu (2010) found moisture, lipid and ash (as \% of muscle) as 54.35, 9.41 and 16.73, respectively in 'lona ilish' (salted hilsa) where ash content agreed with but moisture and lipid contents differ from the present study. Since fresh hilsa which is of high fatty fish group is transformed to lona hilsa; it is not unlikely to have high fat content in salted hilsa.

Shamim et al. (2011) studied the proximate composition of different portion of hilsa collected from two regions of the Bay of Bengal and found the highest protein content $(21.89 \%)$ in ventral where lowest $(20.50 \%)$ in caudal region. In this study, we found highest protein content $(23.62 \pm 0.28 \%)$ in dorsal region of fresh sample and lowest $(20.79 \pm 0.17 \%)$ in dorsal region of salted fish. However, variation in proximate composition of fish flesh may vary with different portions of fish body, species variation, season, age and the feeding habit of fish.

Traditionally, the fishermen themselves processed the fish for salted hilsa. Hygienic conditions were far from satisfactory in the manufacturing units. Sometimes fish were not even washed before being cut. Secondly, the crude salt used was cheap and of unknown quality. Quality of the product largely depended on the freshness of the raw fish, removal of water during dry salting, period of maturation, concentration of brine etc. The lack of proper knowledge, facilities and carelessness of the fish retailers about microbiological quality of the fresh and salted fish was evident from the study. The result also indicated 
that the hygienic condition and sanitation facilities were not good in the markets of Dhaka city.

Fish play a significant role in the national economy of Bangladesh. Tenualosa ilisha is very rich in nutritional properties and bacterial load in salted hilsa is less compare to that of raw hilsa in different market of Dhaka city. Moreover, there was no Shigella-Salmonella and Vibrio spp. in the salted hilsa. Regular monitoring on local markets and on proper salting process should be done to avoid bacterial contamination and to maintain good nutritional status of both fresh and salted hilsa.

\section{LITERATURE CITED}

ALAM, A.K.M.N. 2010. Post-harvest Loss Reduction in Fisheries in Bangladesh: A way Forward to Food Security. Final Report of NFPCSP-FAO, PR\#5/08 project. Food and Agriculture Organization of the United Nations, Dhaka. $171 \mathrm{pp}$.

AOAC. 1995. Official Methods of Analysis of AOAC International, $16^{\text {th }}$ ed., Washington DC

BALACHANDRAN, K.K. 2001. Post Harvest Technology of Fish and Fish Products. Daya publishing house, Delhi, India. pp. 77.

BOYD, C.E. 1990. Water Quality in Ponds for Aquaculture. Birmingham Publishing Co., Alabama, USA. $480 \mathrm{pp}$.

CLESCERL, L.S., GREENBERG A.E. and EATON, A.D. 1999. Standard method for examination of water and wastewater (20 th ed.). APHA. Washington DC.

CLUCAS, I.J. and WARD, A.R. 1996. Post harvest fisheries development: a guide to handling, preservation, processing and quality. National resources institute. Chatham Maritime, Kent MTB, UK.pp.384-389

DOF. 2013. National Fish Week 2013 Compendium (In Bengali). DOF, Ministry of Fisheries and Livestock, Bangladesh. 144p.

EKLUND, C. and LANKFORD, C.E. 1967. Laboratory manual for general microbiology. Prentice-Hall International, Inc., London. pp. 299.

HATHA, A.A.M., PAUL, N. and RAO, B. 1998. Bacteriological quality of quick frozen (IQF) raw and cooked ready to eat shrimp products from farm raised black tiger shrimp (Penaeus monodon) . Food Micro. 15: 177-183.

ICMSF. 1986. Microorganisms in food. Vol. 2, Sampling for microbiological analysis: principles and specific applications. International Commission on the Microbiological Specification of Foods (ICMSF). Univ. Toronto Press, Toronto.

IMMACUlATE, K., SINDUJA, P., VELAMMAL, A. and PATTERSON, J. 2013. Quality and shelf life status of salted and sun dried fishes of Tuticorin fishing villages in different seasons. Int. Food Res. J. 20: 1855-1859

ITO, H., RASHID, H.O., SANGTHIN, N., ADUIYATHAM, P., RATTAGOOAL, P. and ISHIJAKI, I. 1993. Effect of gamma irradiation on frozen shrimp for decontamination to reduce microbial contamination. Radiation Phy. Che. 34 :1009-1011.

JACQUOT, R. 1961. Organic constituent of fish and other aquatic animals. In: Fish as Food (Ed. Borgstrom, G.), Academic Press, New York and London. pp. 145-209.

KHURSEED, J. and MOSHARAFF. 1998. Seasonal changes on biochemical composition of fresh water murrel Ophiocephalus punctatus (Bloch). Hydrobiologia 32: 206-213 
LAKSHMANAN, R., VENUGOPAL, V., VENKETSASHRAVAN, K. and BANGIRWIR, D.R. 1999. Bulk Preservation of Small Pelagic Fish by Gamma Radiation. Food Reg. Intl. 32: 707-713.

MAJUMDAR, R.K., BASU, S. and NAYAK, B.B. 2005. Studies on the biochemical changes during fermentation of salt-fermented Indian shad (Tenualosa ilisha). J. Aqua. Food Pro. Technol. 15: 53-69

MAJUMDAR, R.K. and BASU, S. 2010. Characterization of the traditional fermented fish product Lona ilish of Northeast India. Indian J. Ttradit. Know. 9: 453-458

MUNCE, H.R. 1980. Principles of food packaging - an international guide. Published by the arrangement with FAO of United Nations. pp. 19-21.

NILLA, S.S., KHAN, M.A.R., KHAN, M.M.R., AHSAN, D.A. and MUSTAFA, M.G. 2012. Bacteriological quality of marketed mola fish, Amblypharyngodon mola from Dhaka metropolis. Bangladesh $J$. Zool. 40: $77-88$

RAHMAN, A.K.M. 2005. Freshwater Fishes of Bangladesh, 2nd ed., Zool. Soc. Bangladesh, Dhaka, Bangladesh, xviii+ $394 \mathrm{pp}$.

SHAMIM, M.A.H., AHMED, M.K. and ABDULlAH, A.T.M. 2011. Proximate composition of different portion of hilsa, Tenualosa ilisha from two regions of the Bay of Bengal in Bangladesh. Dhaka Univ. J. Biol. Sci. 20: 109-115

SHAMSUZZAMAN, M.M., MAZUMDER, S.K., SIDDIQUE, M.A. and MIAH, M.N.U. 2011. Microbial quality of hilsa shad (Tenualosa ilisha) at different stages of processing. J. Bangladesh Agri. Univ. 9: 339-344

SHEWAN, J.M., 1970. Bacteriological Standards for Fish and Fishery Products, Academic press. New York. Pp 193.

SRIVASTAVA, C.B.L. 1985. A text book of fishery science and Indian fisheries, Kitab Mohal, Allahabad, India. pp. 47-86.

SULTANA, S., ABDULLAH-AL-MAHIN and CHOWDHURY, M.A.Z. 2008. Microbial load of salted hilsa (Tenualosa ilisha) and its preservation by radiation. Nuclear science and applications 17: 96-101

TAKAGI, T., HAYASHI, K. and ITABASHI, Y. 1984. Toxic effect of free unsaturated fatty acid in mouse assay of diarrhatic shellfish toxin by intraperitoneal injection. Bull. Japan Sci. fish. 50: $1413-1418$. 